\title{
Surface Interaction between $\mathrm{H}_{2}$ and $\mathrm{CO}_{2}$ on $\mathrm{Rh} / \mathrm{Al}_{2} \mathrm{O}_{3}$, Studied by Adsorption and Infrared Spectroscopic Measurements
}

\author{
F. Solymosi, A. ERdöhelyi, and M. Kocsis \\ Reaction Kinetics Research Group, The University, P.O. Box 105, Szeged, Hungary
}

Received January 9, 1980; revised April 14, 1980

\begin{abstract}
The low-temperature interaction between $\mathrm{H}_{2}+\mathrm{CO}_{2}$ on $\mathrm{Rh} / \mathrm{Al}_{2} \mathrm{O}_{3}$ was investigated by adsorption and infrared spectroscopic measurements. Adsorption studies indicated that the presence of $\mathrm{H}_{2}$ greatly enhances the uptake of $\mathrm{CO}_{2}$ by $\mathrm{Rh} / \mathrm{Al}_{2} \mathrm{O}_{3}$ catalyst. Infrared spectroscopic studies revealed that adsorbed formate and $\mathrm{CO}$ are formed in the low-temperature interaction between $\mathrm{H}_{2}$ and $\mathrm{CO}_{2}$. On comparison of the spectrum of adsorbed $\mathrm{CO}$ with that obtained after coadsorption of the $\mathrm{H}_{2}+$ $\mathrm{CO}_{2}$ mixture, it appeared that (i) the doublet due to twin $\mathrm{CO}\left(\mathrm{Rh} / \mathrm{CO} /{ }_{2}\right)$ was completely missing, (ii) the linearly bonded $\mathrm{CO}$ appeared at lower frequency, $2020-2039 \mathrm{~cm}^{-1}$, and (iii) no significant change was observed in the position of the bridged $\mathrm{CO}$. The apparent activation energy of the formation of formate ion was calculated to be $4.2 \mathrm{kcal} / \mathrm{mol}$, which is markedly lower than that determined for pure $\mathrm{Al}_{2} \mathrm{O}_{3}$, indicating the great promoting effect of $\mathrm{Rh}$. Possible mechanisms of the $\mathrm{H}_{2}+\mathrm{CO}_{2}$ interaction are discussed.
\end{abstract}

\section{INTRODUCTION}

Rhodium is a very effective catalyst for hydrogenation of $\mathrm{CO}_{2}$ to $\mathrm{CH}_{4}(1,2)$. The rate per unit surface area of $\mathrm{Rh}$ is considerably higher than that for hydrogenation of $\mathrm{CO}$ either on polycrystalline $\mathrm{Rh}(l)$ or on alumina-supported $\mathrm{Rh}(2)$. The value of the activation energy, $16 \mathrm{kcal} / \mathrm{mol}$, is also lower for $\mathrm{CH}_{4}$ formation from a $\mathrm{H}_{2}+\mathrm{CO}_{2}$ mixture than from a $\mathrm{H}_{2}+\mathrm{CO}$ mixture. These results suggest that the most important elementary steps in $\mathrm{CH}_{4}$ formation, the reaction of surface intermediates, occur favorably when $\mathrm{CO}_{2}$ is used as a reactant. In order to obtain a deeper insight into the nature of the $\mathrm{H}_{2}+\mathrm{CO}_{2}$ reaction, in the present work the surface interaction between $\mathrm{H}_{2}$ and $\mathrm{CO}_{2}$ has been investigated by adsorption and infrared spectroscopic measurements on the same $\mathrm{Rh} / \mathrm{Al}_{2} \mathrm{O}_{3}$ sample as used in the catalytic studies (2).

\section{EXPERIMENTAL}

Materials. The catalysts were prepared by impregnating an alumina support (Degussa $P \quad 110 \mathrm{Cl}$ ) with a solution of $\mathrm{RhCl}_{3} \cdot 3 \mathrm{H}_{2} \mathrm{O}$ to yield a nominal $5 \mathrm{wt} \%$ metal. The impregnated powders were dried at $393 \mathrm{~K}$. For catalytic and adsorption measurements, small fragments of slightly compressed pellets were used. For infrared studies, transparent thin $30 \times 10-\mathrm{mm}$ wafers were prepared at high pressures $(1600$ atm). The sample thickness varied in the range $15-20 \mathrm{mg} / \mathrm{cm}^{2}$. Before any measurements, the catalyst was oxidized with 100 Torr $\mathrm{O}_{2}$ for $30 \mathrm{~min}$ and reduced with 100 Torr $\mathrm{H}_{2}$ for $30 \mathrm{~min}$ at $673 \mathrm{~K}$ in situ. After oxidation and reduction, the sample was evacuated prior to adsorption and infrared spectroscopic measurements or flushed with pure $\mathrm{N}_{2}$ for pulse experiments at 673 $\mathrm{K}$. The dispersity of Rh was $30.2 \%$.

The gases used were initially of commercial purity. They were purified by fractional distillation $\left(\mathrm{CO}_{2}\right)$ or by adsorbing the impurities at the temperature of liquid air using a molecular sieve. The purities of the gases were checked by mass spectrometry.

Methods. Adsorption measurements were made in a Sartorius microbalance. Infrared spectra were recorded by a Specord 75 IR double-beam spectrometer (Zeiss, Jena). The instrument scans the region from 4000 to $400 \mathrm{~cm}^{-1}$ at a rate of 
from 0.1 to 27 wavenumbers/sec. In order to enhance the sensitivity, an appropriate attenuator was used in the reference light path. The resolution was better than \pm 5 $\mathrm{cm}^{-1}$. The apparatus was calibrated with $0.02-\mathrm{mm}$-thick polystyrene foil and also with a gas cell containing $\mathrm{CO}$ at 150 Torr.

A Kiselev-type infrared cell was used with $\mathrm{NaCl}$ windows. A detailed description of the cell has been given elsewhere (3). The cell was connected to a traditional gashandling and vacuum system. All spectra were recorded at the temperature of the infrared beam, about $313 \mathrm{~K}$.

The dispersity of the supported Rh was determined by $\mathrm{H}_{2}$ adsorption at $298 \mathrm{~K}$ and atmospheric pressure using dynamic impulse methods $(4,5)$. The $\mathrm{H}_{2}$ uptake was 73 $\mu \mathrm{mol} / \mathrm{g}$.

\section{RESULTS AND DISCUSSION}

\section{Adsorption Studies}

The adsorption of $\mathrm{CO}_{2}$ on $\mathrm{Rh} / \mathrm{Al}_{2} \mathrm{O}_{3}$ begins as a very fast process, the extent of which decreases with increase of the adsorption temperature (Fig. 1). This fast adsorption is followed by very slow adsorption of $\mathrm{CO}_{2}$. About 30-50\% of the adsorbed $\mathrm{CO}_{2}$ can be pumped off at the temperature of adsorption. Almost the same gas uptakes were registered on the $\mathrm{Al}_{2} \mathrm{O}_{3}$ support alone, which may indicate that $\mathrm{CO}_{2}$ does not

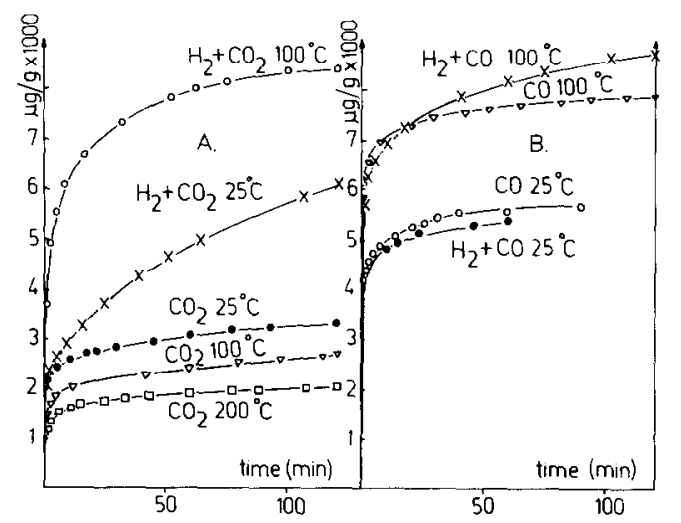

FIG. 1. Adsorption of 20 Torr $\mathrm{CO}_{2}$ and 40 Torr $\mathrm{H}_{2}+$ $\mathrm{CO}_{2}(1: 1)(\mathrm{A})$, and 20 Torr $\mathrm{CO}$ and 40 Torr $\mathrm{H}_{2}+\mathrm{CO}$ (1:1) (B) on reduced $\mathrm{Rh} / \mathrm{Al}_{2} \mathrm{O}_{3}$ at different temperatures.

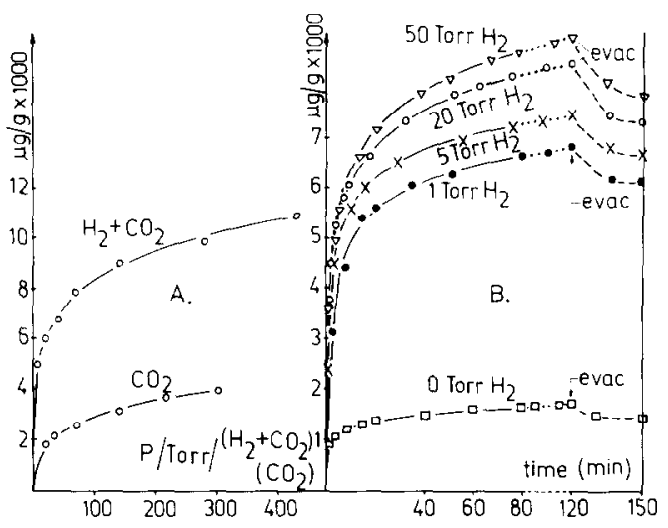

FIG. 2. (A) Adsorption isotherms of $\mathrm{CO}_{2}$ and $\mathrm{H}_{2}+$ $\mathrm{CO}_{2}(1: 1)$ on $\mathrm{Rh} / \mathrm{Al}_{2} \mathrm{O}_{3}$ at $373 \mathrm{~K}$. (B) The effect of amount of $\mathrm{H}_{2}$ on the gas uptake from the $\mathrm{H}_{2}+\mathrm{CO}_{2}$ mixture on $\mathrm{Rh} / \mathrm{Al}_{2} \mathrm{O}_{3}$ at $373 \mathrm{~K}$. The pressure of $\mathrm{CO}_{2}$ was 20 Torr.

chemisorb on $\mathrm{Rh}$, or at least that its adsorption is very limited.

In contrast, as Fig. 1 shows, $\mathrm{CO}$ adsorbs strongly and to a greater extent on Rh. On $\mathrm{Al}_{2} \mathrm{O}_{3}$ the adsorption of $\mathrm{CO}$ is much less than that of $\mathrm{CO}_{2}$. As regards the adsorption of $\mathrm{H}_{2}$, we refer to the determination of dispersity of $\mathrm{Rh}$ by $\mathrm{H}_{2}$ chemisorption.

In subsequent measurements the coadsorption of $\mathrm{H}_{2}+\mathrm{CO}_{2}(1: 1)$ was investigated. The uptake from this gas mixture was markedly larger than the sum of the separately adsorbed gases (Fig. 1). With an increase in the pressure of the $\mathrm{H}_{2}+\mathrm{CO}_{2}$ mixture, the amount of gas uptake greatly increased (Fig. 2). Approximate saturation was reached at 600 Torr. In this case the amount of strongly held adsorbed gases that remaining after $30 \mathrm{~min}$ evacuation at $373 \mathrm{~K}$ was $9.38 \mathrm{mg} / \mathrm{g}$ catalyst. Under similar conditions $2.27 \mathrm{mg} \mathrm{CO}_{2}$ remained adsorbed on $1 \mathrm{~g}$ catalyst. (No such phenomenon occurred on alumina in the absence of Rh.) In contrast to the adsorption of $\mathrm{CO}_{2}$, on evacuation at 298 or $373 \mathrm{~K}$ only 10 $15 \%$ of the adsorbed gases was desorbed and the extent of gas uptake from the $\mathrm{H}_{2}$ $+\mathrm{CO}_{2}$ mixture increased with the temperature up to $303 \mathrm{~K}$.

From further experiments it appeared that the addition of even 1 Torr $\mathrm{H}_{2}$ to the 
$\mathrm{CO}_{2}$ greatly enhanced the amount of gas adsorbed. After increasing of the pressure of $\mathrm{H}_{2}$, the extent of gas uptake increased further (Fig. 2).

When $\mathrm{H}_{2}$ was preadsorbed at 298 or 373 $\mathrm{K}$ for a given time, and the gaseous and weakly adsorbed $\mathrm{H}_{2}$ was then evacuated, an appreciable increase of subsequent $\mathrm{CO}_{2}$ adsorption was also experienced. The extent of enhanced $\mathrm{CO}_{2}$ adsorption increased with the amount of chemisorbed $\mathrm{H}_{2}$, but it was always less than the value obtained during the coadsorption measurements.

A possible reason for the enhanced adsorption from the $\mathrm{H}_{2}+\mathrm{CO}_{2}$ mixture is that adsorbed hydrogen reacts with $\mathrm{CO}_{2}$, producing $\mathrm{CO}$

$$
2 \mathrm{H}_{(\mathrm{a})}+\mathrm{CO}_{2}=\mathrm{CO}_{(\mathrm{a})}+\mathrm{H}_{2} \mathrm{O}_{(\mathrm{a})}
$$

which, as Fig. I shows, adsorbs on $\mathrm{Rh}$ to a greater extent than does $\mathrm{CO}_{2}$. In harmony with this assumption, preadsorbed $\mathrm{CO}$ markedly decreased the extent of the enhanced adsorption from the $\mathrm{H}_{2}+\mathrm{CO}_{2}$ mixture (Fig. 3). On the other hand, when the $\mathrm{H}_{2}+\mathrm{CO}_{2}$ gas mixture was adsorbed on $\mathrm{Rh} / \mathrm{Al}_{2} \mathrm{O}_{3}$ for $60 \mathrm{~min}$ at $298 \mathrm{~K}$, practically no significant change occurred in the subse-

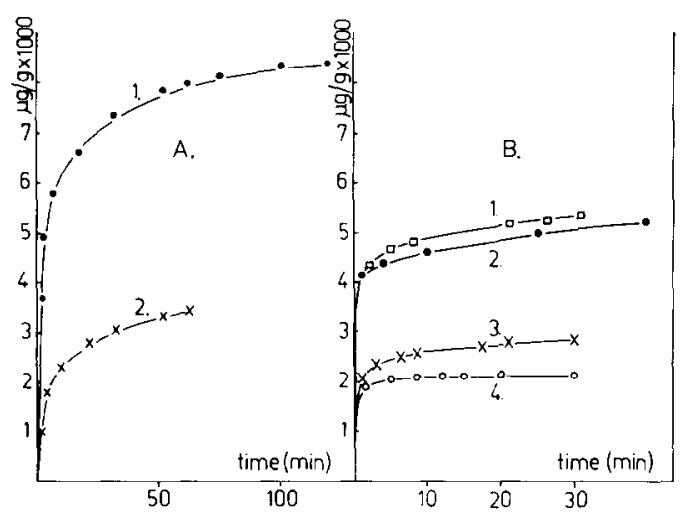

FIG. 3. (A) Adsorption of 40 Torr $\mathrm{H}_{2}+\mathrm{CO}_{2}(1: 1)$ at $373 \mathrm{~K}$ (1) on reduced $\mathrm{Rh} / \mathrm{Al}_{2} \mathrm{O}_{3}$, and (2) on the sample saturated with $\mathrm{CO}$ at $298 \mathrm{~K}$. (B) Adsorption of $\mathrm{CO}$ at $298 \mathrm{~K}$ (1) on reduced $\mathrm{Rh} / \mathrm{Al}_{2} \mathrm{O}_{3}$, (2) on samples treated with 40 Torr $\mathrm{H}_{2}+\mathrm{CO}_{2}(1: 1)$ for $60 \mathrm{~min}$ at $298 \mathrm{~K}$, (3) for $60 \mathrm{~min}$ at $373 \mathrm{~K}$, and (4) on the sample saturated with $\mathrm{H}_{2}+\mathrm{CO}_{2}(1: 1)$ at $373 \mathrm{~K}$. quent adsorption of $\mathrm{CO}$. After adsorption of the $\mathrm{H}_{2}+\mathrm{CO}_{2}$ mixture at $373 \mathrm{~K}$, however, when an enhanced gas uptake occurred, the extent of subsequent adsorption of CO at $298 \mathrm{~K}$ was greatly reduced (Fig. 3).

As mass-spectrometric analysis of the gas phase during the coadsorption of $\mathrm{H}_{2}+$ $\mathrm{CO}_{2}$ at $298-373 \mathrm{~K}$ did not reveal any reaction; we had to assume that all the products of the water-gas shift reaction remained adsorbed on the $\mathrm{Rh} / \mathrm{Al}_{2} \mathrm{O}_{3}$ surface.

Assuming that the $\mathrm{CO}$ formed in the above reaction is adsorbed on the $R h$ and that the water is adsorbed on the alumina, from the amount of gas uptake from the $\mathrm{H}_{2}$ $+\mathrm{CO}_{2}$ mixture (at saturation and at $373 \mathrm{~K}$ ) we determined that $148 \mu \mathrm{mol} \mathrm{CO} / \mathrm{g}$ and 148 $\mu \mathrm{mol} \mathrm{H}_{2} \mathrm{O} / \mathrm{g}$ are formed in the surface reaction.

The maximum uptake of $\mathrm{CO}$ by the $\mathrm{Rh}$ of this sample under more favorable conditions (at $373 \mathrm{~K}$ and at 600 Torr $\mathrm{CO}$ ), however, was $165 \mu \mathrm{mol} / \mathrm{g}$, which is only slightly higher than the above value.

In the interpretation of this result, one can assume that the adsorbed hydrogen promotes the adsorption of $\mathrm{CO}$. As one $\mathrm{Rh}$ atom is capable of adsorbing two CO molecules, it can also be assumed that the formation of this surface species is more favorable in the presence of $\mathrm{H}_{2}$. The results presented in Fig. 1, however, show that this is not the case, for practically the same gas uptake was obtained from the $\mathrm{H}_{2}+\mathrm{CO}$ mixture as from $\mathrm{CO}$ alone, and, as will be shown later, the adsorbed hydrogen hinders the formation of the twin structure of adsorbed $\mathrm{CO}$.

Accordingly, it seems more likely that, in addition to the formation of $\mathrm{CO}$ and $\mathrm{H}_{2} \mathrm{O}$, the surface interaction between $\mathrm{H}_{2}$ and $\mathrm{CO}_{2}$ on $\mathrm{Rh} / \mathrm{Al}_{2} \mathrm{O}_{3}$ produces a surface complex which also contributes to the increased gas uptake.

In order to obtain a deeper insight into the surface processes during the coadsorption of the $\mathrm{H}_{2}+\mathrm{CO}_{2}$ mixture, infrared spectroscopic measurements were carried out. 


\section{Infrared Spectroscopic Measurements}

Adsorption of $\mathrm{CO}_{2}$ at 25 Torr on reduced $5 \mathrm{wt} \% \mathrm{Rh} / \mathrm{Al}_{2} \mathrm{O}_{3}$ at $298-373 \mathrm{~K}$ produced bands at 1625-1640,1436, and $1230 \mathrm{~cm}^{-1}$ (Fig. 4), which can be attributed to the formation of carbonate species. The intensities of these bands showed a very slight variation with adsorption time and temperature. Similar experiments on alumina resulted in the same infrared spectra.

No bands due to adsorbed $\mathrm{CO}$, indicative of the dissociation of $\mathrm{CO}_{2}$, were observed in the spectra at this pressure. This result, in harmony with the observations of previous workers on $\mathrm{Rh}$ films (6), on polycrystalline $\mathrm{Rh}(7)$, and on alumina-supported $\mathrm{Rh}(8)$, shows that the adsorption of $\mathrm{CO}_{2}$ on $\mathrm{Rh}$ is very weak. In contrast, however, Somorjai et al. $(9,10)$ found that $\mathrm{CO}_{2}$ does chemisorb and dissociate on several faces of Rh single crystals.

From our more detailed investigations concerning this question, we found that the dissociation of $\mathrm{CO}_{2}$ occurs to a small extent on supported $\mathrm{Rh}$, too. The preparation of the catalyst, the dispersity of the $\mathrm{Rh}$, and

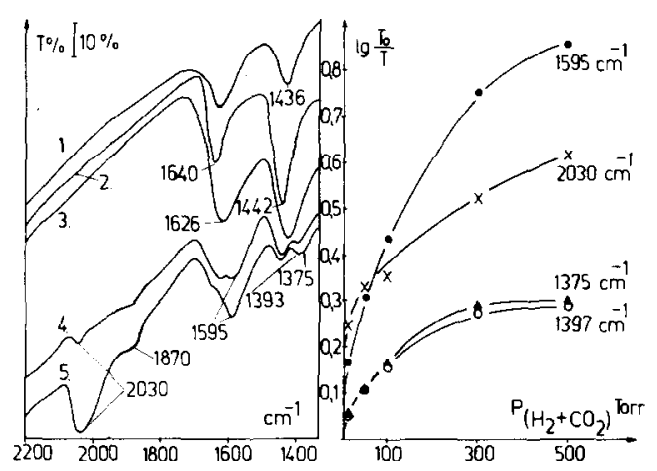

FIG. 4. (A) Infrared spectra observed at room temperature after adsorption of $\mathrm{CO}_{2}$ and $\mathrm{H}_{2}+\mathrm{CO}_{2}(1: 1)$ on $\mathrm{Rh} / \mathrm{Al}_{2} \mathrm{O}_{3}$ and $\mathrm{Al}_{2} \mathrm{O}_{3}$. (1) 25 Torr $\mathrm{CO}_{2}$ on $\mathrm{Rh} / \mathrm{Al}_{2} \mathrm{O}_{3}$ at $298 \mathrm{~K}$, (2) 25 Torr $\mathrm{CO}_{2}$ on $\mathrm{Al}_{2} \mathrm{O}_{3}$ at $298 \mathrm{~K}$, (3) 300 Torr $\mathrm{H}_{2}+\mathrm{CO}_{2}$ on $\mathrm{Al}_{2} \mathrm{O}_{3}$ at $373 \mathrm{~K}$, (4) 50 Torr $\mathrm{H}_{2}+$ $\mathrm{CO}_{2}$ on $\mathrm{Rh} / \mathrm{Al}_{2} \mathrm{O}_{3}$ at $298 \mathrm{~K}$, (5) 50 Torr $\mathrm{H}_{2}+\mathrm{CO}_{2}$ on $\mathrm{Rh} / \mathrm{Al}_{2} \mathrm{O}_{3}$ at $373 \mathrm{~K}$. (B) The intensities of the new bands formed in the surface reaction of $\mathrm{H}_{2}+\mathrm{CO}_{2}$ (1:1) on $\mathrm{Rh} / \mathrm{Al}_{2} \mathrm{O}_{3}$ at $373 \mathrm{~K}$ as a function of $\mathrm{H}_{2}+\mathrm{CO}_{2}$ (1:1) pressure. The points correspond to the stage when the intensities of the bands approached a steady value.

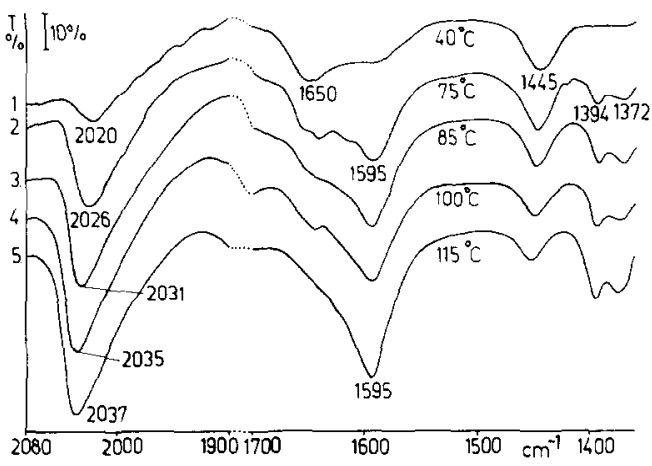

Fig. 5. Infrared spectra observed at room temperature after adsorption of 40 Torr $\mathrm{H}_{2}+\mathrm{CO}_{2}(1: 1)$ on $\mathrm{Rh} / \mathrm{Al}_{2} \mathrm{O}_{3}$ at different temperatures for $5 \mathrm{~min}$. The cell was evacuated at the adsorption temperature before the registration of the spectra.

the nature of the support all have an influence on this process. On the sample used in the present work, weak bands due to $\mathrm{CO}$, indicating the occurrence of dissociation of $\mathrm{CO}_{2}$, appeared at $373 \mathrm{~K}$ when a high pressure (200 Torr) of $\mathrm{CO}_{2}$ was used.

Adsorption of $\mathrm{H}_{2}$ on supported $\mathrm{Rh}$ at 298-673 K produced no detectable absorption bands in the frequency range 1000 $4000 \mathrm{~cm}^{-1}$, in agreement with the observation of Yates et al. (11).

Upon admitting the $\mathrm{H}_{2}+\mathrm{CO}_{2}$ mixture (25 Torr of each gas) into the cell at 298-373 $\mathrm{K}$, the following spectral changes occurred. Even at the beginning of the adsorption, new bands appeared between 2020 and 2039 and at $1870 \mathrm{~cm}^{-1}$ (Fig. 4). In addition, new bands were also identified in the low-frequency region, at 1595,1393 , and 1375 $\mathrm{cm}^{-1}$, and a very weak one at $2914 \mathrm{~cm}^{-1}$. Their intensities slowly grew in time and with the pressure of $\mathrm{H}_{2}+\mathrm{CO}_{2}$ (Fig. 4). On raising the adsorption temperature, the intensity of the band between 2020 and 2039 $\mathrm{cm}^{-1}$ increased up to $388 \mathrm{~K}$, but it decreased above this temperature. In contrast, the intensities of the other new bands grew with the increase of the adsorption temperature up to $573 \mathrm{~K}$. At the same time the intensities of the bands due to surface carbonate gradually decreased (Fig. 5).

It is to be mentioned that these bands 
were not detected on pure alumina under the same conditions. They appeared, however, when the $\mathrm{H}_{2}+\mathrm{CO}_{2}$ mixture $(300$ Torr) was adsorbed on alumina at the higher temperatures of 473-673 $\mathrm{K}$ and then evacuated at $298 \mathrm{~K}$.

In order to facilitate the interpretation of the above results, we examined the infrared spectra of adsorbed $\mathrm{CO}$ and $\mathrm{HCOOH}$, recorded under the same conditions.

Infrared spectroscopic measurements on the adsorption of $\mathrm{CO}$ over $\mathrm{Rh} / \mathrm{Al}_{2} \mathrm{O}_{3}$ unequivocally show that three kinds of adsorbed $\mathrm{CO}$ exist on the surface $(12-21)$ : a twin structure, $\mathrm{Rh}_{\mathrm{CO}}^{\mathrm{CO}}$, absorbing at 2101

and $2035 \mathrm{~cm}^{-1}$; a linear form, $\mathrm{Rh}-\mathrm{CO}$, absorbing at $2060-2070 \mathrm{~cm}^{1}$; and a bridged form, ${ }_{\mathrm{Rh}}^{\mathrm{Rh}} \mathrm{CO}$, yielding a broad band at $1855-1870 \mathrm{~cm}^{-1}$. The most interesting feature of the adsorption of $\mathrm{CO}$ is the formation of the twin structure. It is now gener-

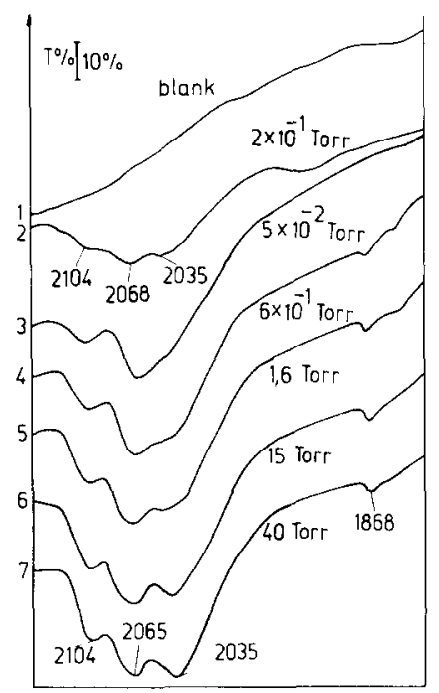

FIG. 6. Infrared spectra observed at room temperature atter adsorption of $\mathrm{CO}$ of different pressure on $\mathrm{Rh} / \mathrm{Al}_{2} \mathrm{O}_{3}$ at $\mathrm{H} 298$ (spectrum 2) and $373 \mathrm{~K}$ (spectra 3-7). ally believed that the high dispersity of the $\mathrm{Rh}$ favors the formation of this species. In the further details, however, opinions differ.

While French workers $(16,17)$ assign its formation to $\mathrm{Rh}(\mathrm{I})$ formed during the dissociation of $\mathrm{CO}$ on Rh, Yates et al. (19) assume that this species forms on atomically dispersed $\mathrm{Rh}$ atoms. Yates et al. (20) attribute its formation to the edge or corner atoms of two-dimensional rafts of $\mathrm{Rh}$ atoms.

As the spectra in Fig. 6 show, the above surface species were formed on our sample (5 wt $\% \mathrm{Rh} / \mathrm{Al}_{2} \mathrm{O}_{3}$ ) too. The doublet due to the twin structure appeared at 2104 and $2035 \mathrm{~cm}^{-1}$. Their intensities were almost equal. Weak bands due to bridged $\mathrm{CO}$ appeared at $1860-1870 \mathrm{~cm}^{-1}$, and linearly bonded $\mathrm{CO}$ produced a band at $2060-2070$ $\mathrm{cm}^{-1}$. Its intensity increased with higher pressure and temperature.

On comparison of these spectra with that obtained after coadsorption of the $\mathrm{H}_{2}+$ $\mathrm{CO}_{2}$ mixture, the following can be stated about the latter spectrum:

(i) the doublet due to twin $\mathrm{CO}$ was completely missing;

(ii) the linearly bonded $\mathrm{CO}$ appeared at a somewhat lower frequency, 2020-2039 $\mathrm{cm}^{-1}$;

(iii) no significant change could be observed in the appearance of the bridged CO.

The absence of the twin structure cannot be attributed to the low surface concentration of $\mathrm{CO}$, as the above surface structures appeared at all coverages of $\mathrm{CO}$ (Fig. 6). It is more probable that the adsorbed hydrogen prevents the formation of the twin structure, and that instead $\mathrm{Rh}_{\mathrm{CO}_{\mathrm{CO}}}^{\mathrm{H}}$ (or $\mathrm{H}$ $\mathrm{Rh}-\mathrm{H}$ ) is formed. The fact that the vibra- 
tion of this species is somewhat lower than that of unperturbed linearly bonded $\mathrm{CO}$ is in agreement with the expectation that the $\mathrm{H}$ chemisorbed to the rhodium atom of a carbonyl is electron-donating, which increases the $\pi$-donation from the rhodium into the antibonding $\pi$ orbital of the $\mathrm{CO}$, resulting in a decrease in $\nu_{\mathrm{CO}}$. This shift in $\nu_{\text {Co }}$ was observed during the dissociative adsorption of $\mathrm{H}_{2} \mathrm{CO}$ on highly dispersed $\mathrm{Rh}$ supported by alumina, when the twin band was also missing $(/ I)$. It must be mentioned, however, that the admission of even $5.10^{-3}-10^{-1}$ Torr $\mathrm{CO}$ at $298 \mathrm{~K}$ onto a surface treated with the $\mathrm{H}_{2}+\mathrm{CO}_{2}$ gas mixture at $573 \mathrm{~K}$ for $10 \mathrm{hr}$ produced a twin band at 2104 and $2038 \mathrm{~cm}^{-1}$. This may indicate that the $\mathrm{CO}$ formed in the $\mathrm{H}_{2}+\mathrm{CO}_{2}$ surface reaction adsorbs on different sites, or in the presence of a larger amount of $\mathrm{CO}$ the adsorbed hydrogen will be replaced by $\mathrm{CO}$. Analysis of the gas phase confirms this latter assumption.

Introduction of a very small amount of $\mathrm{HCOOH}$ gave very intense bands at 1585 and $1380 \mathrm{~cm}^{-1}$, on either $\mathrm{Rh} / \mathrm{Al}_{2} \mathrm{O}_{3}$ or $\mathrm{Al}_{2} \mathrm{O}_{3}$. A very weak band at 2914-2921 $\mathrm{cm}^{-1}$ was also identified. In agreement with previous workers (22-25), the 1585 and $1380 \mathrm{~cm}^{-1}$ bands are assigned to the asymmetric and symmetric $\mathrm{O}-\mathrm{C}-\mathrm{O}$ stretching vibrations of adsorbed formate ion. The weak band at $2914-2921 \mathrm{~cm}^{-1}$ is probably due to a $\mathrm{CH}$ stretching vibration. Above $373 \mathrm{~K}$ a weak band at $2030 \mathrm{~cm}^{-1}$ also appeared in the spectra $\left(\mathrm{Rh} / \mathrm{Al}_{2} \mathrm{O}_{3}\right.$, Fig. 7).

Comparison of these spectra with that obtained during the coadsorption of $\mathrm{H}_{2}+$ $\mathrm{CO}_{2}$ on $\mathrm{Rh} / \mathrm{Al}_{2} \mathrm{O}_{3}$ permits the safe conclusion that formate groups are also formed in the $\mathrm{H}_{2}+\mathrm{CO}_{2}$ interaction. The formation of formate bands in the surface interaction between $\mathrm{H}_{2}$ and $\mathrm{CO}_{2}$ was recently observed on $\mathrm{Pd} / \mathrm{Al}_{2} \mathrm{O}_{3}(26)$ and on the other aluminasupported noble metals $(27,28)$. It was also detected in the $\mathrm{H}_{2}+\mathrm{CO}$ reaction over $\mathrm{Ru} / \mathrm{Al}_{2} \mathrm{O}_{3}(29)$ and on pure alumina, too $(25,30)$. As the formate group was identified on $\mathrm{Rh} / \mathrm{Al}_{2} \mathrm{O}_{3}$ even at $298 \mathrm{~K}$, while on the $\mathrm{Al}_{2} \mathrm{O}_{3}$ support it was detected

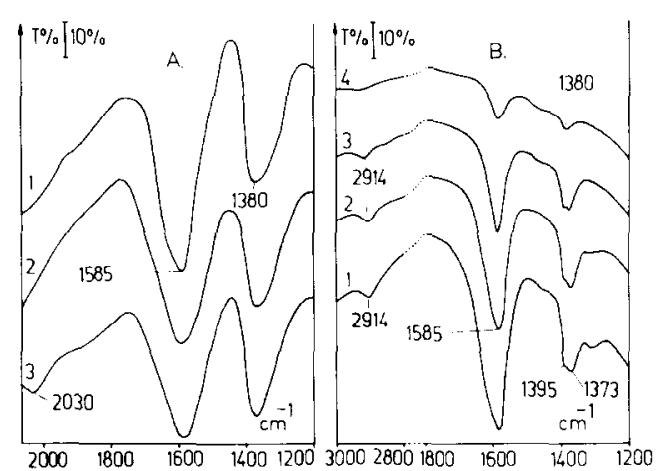

FIG. 7. Infrared spectra of adsorbed formic acid on $\mathrm{Rh} / \mathrm{Al}_{2} \mathrm{O}_{3}$ (A) and $\mathrm{Al}_{2} \mathrm{O}_{3}$ (B). Temperatures and times of evacuation before registration of the spectra: (A) (1) $298 \mathrm{~K}$ for $30 \mathrm{~min}$, (2) $373 \mathrm{~K}$ for $10 \mathrm{~min}$, (3) $573 \mathrm{~K}$ for 10 min. (Amount of $\mathrm{HCOOH}$ introduced: $1.5 \times 10^{-1}$ Torr.) (B) (1) $298 \mathrm{~K}$ for $30 \mathrm{~min}$, (2) $473 \mathrm{~K}$ for $15 \mathrm{~min}$, (3) $573 \mathrm{~K}$ for $15 \mathrm{~min}$, (4) $673 \mathrm{~K}$ for $15 \mathrm{~min}$. (Amount of $\mathrm{HCOOH}$ introduced: $6.5 \times 10^{-2}$ Torr.)

only above $573 \mathrm{~K}$, the favorable effect of $\mathrm{Rh}$ on the formation of formate is evident.

The possible role of $\mathrm{Rh}$ is to activate the $\mathrm{H}_{2}$ molecule. The adsorbed hydrogen atoms react with $\mathrm{CO}_{2}$ yielding formate groups:

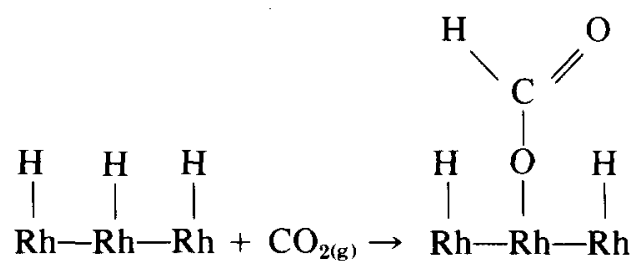

Taking into account the observations that $\mathrm{CO}$ is also formed and that the intensities of the bands due to formate ion increase in time and also with elevation of the temperature, we may assume that a part of the formate decomposes (reactions 3 and 4) on $\mathrm{Rh}$ and the remainder migrates from $\mathrm{Rh}$ onto the alumina support, on which it is much more stable (reaction 5). In the presence of a large excess of $\mathrm{H}_{2}$, the twin structure cannot develop, and instead

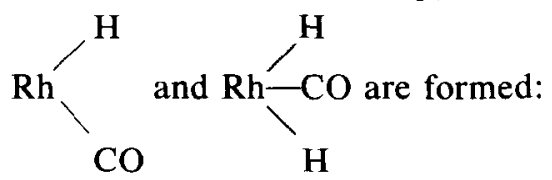




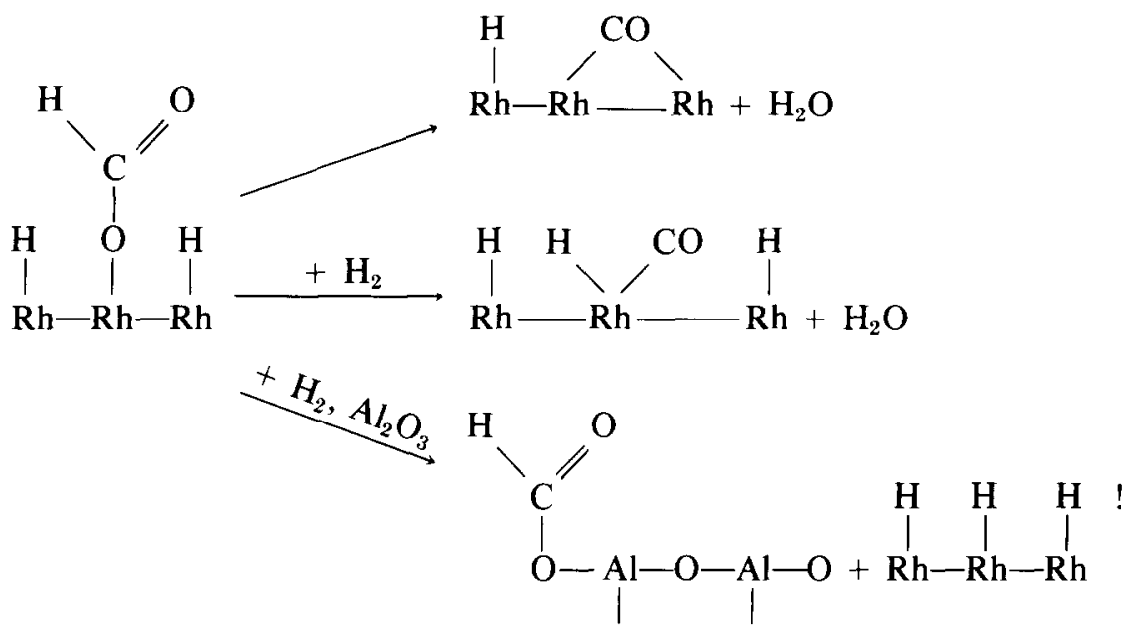

Control measurements showed that $\mathrm{Rh}$ can catalyze the decomposition of formic acid above $373 \mathrm{~K}$, yielding $\mathrm{CO}, \mathrm{H}_{2} \mathrm{O}, \mathrm{H}_{2}$, and $\mathrm{CO}_{2}$. On $\mathrm{Al}_{2} \mathrm{O}_{3}$, measurable decomposition was observed only above $473 \mathrm{~K}$. It is very likely that the migration of formate from $\mathrm{Rh}$ onto alumina is a very fast process at $373 \mathrm{~K}$, as there is no indication of the presence of rhodium formate in the spectra.

Although this explanation seems to be the most probable one, we cannot exclude the possibility that the formation of formate groups occurs on the alumina support. The hydrogen atoms formed in the dissociative adsorption on $\mathrm{H}_{2}$ of $\mathrm{Rh}$ migrate to the adjacent acceptor sites on the alumina, in the present case the adsorbed $\mathrm{CO}_{2}$, which is probably in the form of hydrocarbonate $(3 l)$, producing surface formate group:

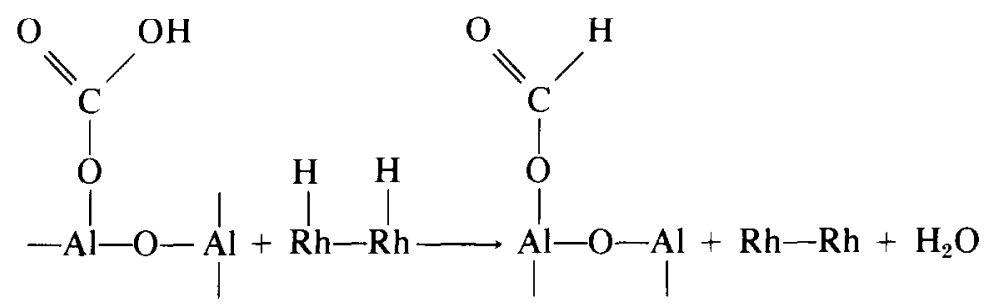

This formate group may diffuse farther, or, interacting with adjacent $\mathrm{Rh}$ atoms, decomposes into the products of Eqs. (2) and (3).

The following experiments show that this process can contribute, at least to a small extent, to the observed phenomena. When the $\mathrm{Rh} / \mathrm{Al}_{2} \mathrm{O}_{3}$ surface was saturated with $\mathrm{CO}_{2}$ at $298 \mathrm{~K}$ and, after a short evacuation at $10^{-3}$ Torr, 50 Torr $\mathrm{H}_{2}$ was introduced, there was no indication of the formation of formate groups. This indicates that the mi- gration of $\mathrm{H}$ atoms from $\mathrm{Rh}$ to alumina is very limited in this case. At $373 \mathrm{~K}$, however, although the intensities of the carbonate species at 1630 and $1457 \mathrm{~cm}^{-1}$ after evacuation became one-third of those observed at $298 \mathrm{~K}$, weak bands characteristic of the formate groups appeared in the spectra.

We may attempt now to calculate the amounts of formate formed in the lowtemperature interaction of $\mathrm{H}_{2}+\mathrm{CO}_{2}$. A correlation between the absorbance of the 
formate band at $1590 \mathrm{~cm}^{-1}$ and the amount of formate ion on the alumina was given by Amenomiya (25). Using his correlation, the surface concentration of formate ion formed at different temperatures was calculated from the absorbance of the band at $1590 \mathrm{~cm}^{-1}$. In the determination of the surface concentration of formate ions the absorbances were calculated from transmittance results. It should be noted that no variation in the baseline was observed after pretreatment of the samples at $673 \mathrm{~K}$. In order to eliminate the contribution of the formation of formate ion during the registration of the infrared spectra at about 313 $\mathrm{K}$, the cell was evacuated after a certain time at the reaction temperature.

Assuming that the formation of formate ion occurs on $\mathrm{Rh}$, the initial rate can be expressed in terms of the turnover number $\mathrm{N}_{\text {formate }}$, the rate per unit surface area of the metal (Table 1).

From the temperature dependence of these values, the apparent activation energy of the formation of formate was obtained as $4.2 \mathrm{kcal} / \mathrm{mol}$ at $313-388 \mathrm{~K}$. This is markedly lower than the value determined by Amenomiya on pure alumina at 473-573 $\mathrm{K}(20 \mathrm{kcal} / \mathrm{mol})$, indicating that the $\mathrm{Rh}$ effectively promotes the formation of formate ion from the $\mathrm{H}_{2}+\mathrm{CO}_{2}$ mixture.

The maximum amount of formate ion at $373 \mathrm{~K}$ is $266 \mu \mathrm{mol} / \mathrm{g}$ catalyst. As the sur-

\section{TABLE 1}

Formation of Surface Formate Ion at Different Temperatures $^{a}$

\begin{tabular}{ccc}
\hline $\begin{array}{c}\text { Temperature } \\
(\mathrm{K})\end{array}$ & $\begin{array}{c}\text { Amount of formate ion } \\
\text { formed in 5 min } \\
(\mu \mathrm{mol} / \mathrm{g})\end{array}$ & $\begin{array}{c}\mathrm{N}_{\text {formate }} \\
\left(\times 10^{3} \mathrm{sec}^{-1}\right)\end{array}$ \\
\hline 313 & 34.82 & 0.79 \\
333 & 68.55 & 1.55 \\
348 & 76.27 & 1.73 \\
358 & 94.28 & 2.14 \\
373 & 99.76 & 2.27 \\
388 & 148.31 & 3.37 \\
\hline
\end{tabular}

${ }^{a} \mathrm{~N}_{\text {formate }}=$ turnover number (molecules formed/ metal site $\cdot \mathrm{sec}) . \mathrm{E}=4.2 \pm 0.5 \mathrm{kcal} / \mathrm{mol}$. face area of the $\mathrm{Al}_{2} \mathrm{O}_{3}$ is $100 \mathrm{~m}^{2} / \mathrm{g}$, this means that the surface concentration of formate ion is $1.6 \times 10^{14}$ ions $/ \mathrm{cm}^{2}$. This value is almost one order of magnitude larger than that obtained by Amenomiya (30) for pure $\mathrm{Al}_{2} \mathrm{O}_{3}$ at $573 \mathrm{~K}$.

In conclusion, we can state the increased uptake of $\mathrm{CO}_{2}$ by $\mathrm{Rh} / \mathrm{Al}_{2} \mathrm{O}_{3}$ catalysts in the presence of $\mathrm{H}_{2}$ can be attributed to the formation of formate ion, which is located on the alumina support. It has been shown that the low-temperature interaction of $\mathrm{H}_{2}$ and $\mathrm{CO}_{2}$ produces carbonylhydride species containing a single $\mathrm{CO}$ ligand and one or two $\mathrm{H}$ ligands.

\section{REFERENCES}

1. Sexton, B. A., and Somorjai, G. A., J. Catal. 46, 167 (1977).

2. Solymosi, F., and Erdöhelyi, A., J, Mol. Catal. 8, 471 (1980).

3. Solymosi, F., Sárkány, J., and Schauer, A., $J$. Catal. 46, 297 (1977).

4. Freel, J, J. Catal. 25, 139 (1972).

5. Menon, P. G., Sieders, J., Streefkerk, F. J., and Van Keulen, G. J. M., J. Catal. 29, 188 (1973).

6. Yang, A. C., and Garland, C. W., J. Phys. Chem. 61, 1504 (1957).

7. Campbell, C. T., and White, J. M., J. Catal. 54, 289 (1978).

8. Collins, A. C., and Trapnell, B. M. W., Trans. Faraday Soc. 53, 1436 (1957).

9. Castner, D. G., Sexton, B. A., and Somorjai, G. A., Surface Sci. 71, 519 (1978).

10. Castner, D. G., and Somorjai, G. A., Surface Sci. 83, 60 (1979).

11. Yates, J. T., Worley, S. D., Duncan, T. M., and Vaughan, R. W., J. Chem. Phys. 70, 1225 (1979).

12. Garland, C. W., Lord, R. C., and Troiano, P. F., J. Phys. Chem. 69, 1188 (1965),

13. Arai, H., and Tominaga, H., J. Catal. 43, 131 (1976).

14. Yao, M. C., and Rothschild, W. G., J. Chem. Phys. 68, 4774 (1978).

15. Solymosi, F., and Sárkány, J., Appl. Surf. Sci. 3, 68 (1979).

16. Primet, M., Trans. Faraday Soc. I 74, 2570 (1978).

17. Kaufherr, N., Primet, M., Dufaux, M., and Naccache, C., C.R. Acad. Sci. Paris 286, 131 (1978).

18. Kroeker, R. M., Kaska, W. C., and Hansma, P. K., J. Catal. 57, 72 (1979).

19. Yates, J. T., Duncan, T. M., Worley, S. D., and Vaughan, R. W., J. Chem. Phys. 70, 1219 (1979). 
20. Yates, D. J. C., Murrell, L. L., and Prestridge, E. B., J. Catal. 57, 41 (1979).

21. Solymosi, F., Erdöhelyi, A., and Bánsági, T., submitted for publication.

22. Scholten, J. J. F., Mars, P., Menon, P. G., and Van Hardeveld, R., Proc. Int. Congr. Catal., 3rd, 19642,881 (1965).

23. Noto, Y., Fukuda, K., Onishi, T., and Tamaru, K., Trans. Faraday Soc. 63, 2300 (1967).

24. Greenler, R. G., J. Chem. Phys. 37, 2094 (1962).

25. Amenomiya, Y., Appl. Spectrosc. 32, 484 (1978).

26. Kadinov, G., Palazov, A., Shopov, D., Paper presented on the IV Intern. Congress in Varna 1979.

27. Erdöhelyi, A., Thesis, Szeged, 1977.

28. Solymosi, F., Erdöhelyi, A., and Kocsis, M., Trans. Faraday Soc. I., in press.

29. Dalla Betta, R. A., and Shelef, M., J. Catal. 48, 111 (1977).

30. Amenomiya, Y., J. Catal. 57, 64 (1979).

31. Knözinger, H., in "Advances in Catalysis" (D. D. Eley, H. Pines, P. B. Weisz, Eds.), Vol. 25, p. 184. Academic Press, New York, 1976. 